\title{
A study on Perceived Threat, Behavior Change, Lockdown Compliance and Coping Strategies among Indian Adults amid COVID-19 outbreak
}

\author{
Ayushi Dixit ${ }^{1}$, Shweta Singh ${ }^{2}$, Ayushi Gaur ${ }^{3}$, Bandna Gupta ${ }^{4}$, P.K. Dalal ${ }^{5}$ \\ ${ }^{1}$ Clinical Psychologist. Shafa homes deaddiction and rehabilitation centre, Kotdwara, Uttarakhand India \\ ${ }^{2}$ Clinical Psychology NIMHANS, Bangalore India), Ph.D. Additional Professor, Department Of \\ Psychiatry, King George's Medical University, Lucknow, U.P, India \\ ${ }^{3}$ Assistant Professor, Department of Clinical Psychology. AMITY University, Lucknow \\ ${ }^{4}$ Department Of Psychiatry, King George's Medical University, Lucknow \\ ${ }^{5}$ Department Of Psychiatry, King George's Medical University, Lucknow \\ Corresponding author: Shweta Singh \\ Email: shwetabhanu3@gmail.com
}

\begin{abstract}
Introduction: During the current pandemic, threat perception of people during lockdown, any subsequent change in their behaviour, coping mechanisms along with lockdown compliance used to deal with the crisis in the Indian subcontinent have been important. The study aims to explore prevalence of perceived threat, behaviour change, lockdown compliance, and coping strategies amid COVID-19 outbreak in India.

Methodology: This cross-sectional study used a semi-structured online questionnaire. Study applied nonprobability snowball sampling technique for data collection. The survey questionnaire included four sections on (a) socio-demographic variables (b) perceived threat (c) lockdown compliance and behaviour change (d) coping strategies. Descriptive statistical analysis was done for the evaluation of data.

Results: The responses of 1068 participants with a mean age of $32.92 \pm 12.88$ years were included for analysis. Nearly half (51\%) of the participants reported feeling 'very high' anxiety and about $34 \%$ reported to have 'high' anxiety about the spread of coronavirus, on the other hand many $(41.6 \%)$ of them believed that they had very less chances of getting infected with coronavirus. A large population (89.3\%) reported complying to the nationwide lockdown. The major coping mechanism being used by the people is distractions, socializing as well as adaptive coping mechanisms.

Conclusion: In the current scenario, there is a concern for India, as due to surge in persons infected with COVID 19 and an indication towards 'optimism bias ' prevalent in people there are chances of poor compliance with government guidelines on behaviour change. The findings of the study will be helpful in designing programs and government measures for the people aimed at ensuring compliance with the guidelines related to social distancing and sanitization and using adaptive coping strategies.
\end{abstract}

Keywords: Perceived Threat; Behaviour Change; Lockdown Compliance; Coping Strategies; COVID-19 outbreak.

(Paper received $-27^{\text {th }}$ January 2021, Peer review completed $-5^{\text {th }}$ March 2021, Accepted $-18^{\text {th }}$ April 2021)

\section{INTRODUCTION}

The outbreak of novel Corona Virus disease ( $2019 \mathrm{n}-\mathrm{CoV})$ across the globe has led to significant feeling of threat and anxiety associated with this viral infection among all [1-5]. Since perception of threat is never absolute, the severity of experiencing danger and likelihood that a disease could affect a person and his or her family is influenced by cognitive, emotional, socio-cultural and contextual variables [6-8]. The threat 
perception of the disease secures considerable significance as the measures taken by the nations and their implementation by people involve modification in behavior and lifestyle patterns.

From the time WHO declared this health crisis, the countries across the globe have been taking extensive preventive measures like setting up guidelines concerning behavior change related to social distancing and sanitization and enforcing lockdown to prevent the spread of virus [9]. There are unique circumstances across Asian countries including the sociocultural, political and economic realities and hence their manner of responding to the current crisis varies. India has been taking extensive preventive measures in terms of implementing lockdown and issuing guidelines related to behavior change to stop the spread of the virus [10]. For this India observed self -quarantine in the form of 'janta curfew'( public curfew) on 22nd March which was followed by enforcement of Nationwide lockdown from 25 march till 31st May in four phases. The process of 'unlocking' started from 1st June, since then lockdown is restricted to containment zones only. But despite these measures the unavoidable surge in COVID 19 cases continues [11].

Behavior change and lockdown compliance are related to perceived threat regarding lockdown. According to 'protection- motivation theory' [12] threat perception plays a very important role in determining motivation to accommodate and implement behavioural changes to prevent illness. A study from the University of Sheffield and Ulster university found that 1 in 5 men aged 19-21 have been arrested, fined or taken by the police for breaking rules as compared to 1 in 10 women of the same age. It was further revealed that this group was more likely to think that they might not catch the COVID-19 infection and following the guidelines was not worthwhile [13].

The pandemic coupled with lockdown lead to a sense of insecurity and worry among the individuals as these measures have never been a part of life with any individual. Complete Lockdown of the state following pandemic produces a sense of monotony and effecting its citizen's emotions negatively in the form of irritation and disappointment [3]. The coping strategies used during lockdown phase has a direct effect on the psychological health of the individual with active coping strategies like acceptance, positive interpretation and planning associated with positive mental health and well-being while the use of avoidant coping strategies like disengagement and denying adversely effects mental health [14]. In a study on H1N1 pandemic, use of emotion focussed strategies like self-blame, passive resignation and rumination were significantly associated with anxiety symptoms [15].

During the current pandemic, it becomes imperative to comprehend threat perception of people during lockdown, any subsequent change in their behaviour and coping mechanisms used to deal with the crisis in the Indian subcontinent because of its unique sociocultural, political and economic realities. Keeping in mind the role of these variables the present study sought to explore the prevalence of perceived threat, behaviour change, lockdown compliance and coping strategies amid COVID-19 outbreak in India.

\section{METHODOLOGY}

This cross-sectional study was conducted in India with the help of an online questionnaire by using nonprobability snowball sampling technique. The semi-structured self-reported questionnaire was prepared by the investigators which included 4 sections on: (a) The socio-demographic variables included age, gender, occupation, years of education and domicile (b) perceived threat associated with COVID 19 infectionincluded 9 items i.e. anxiety related to COVID 19 (4 items), and Threat of infection (5 items). All items were scored on a 4 point Likert scale (Table 1) (c) lockdown compliance and behavior change - 18 items related to social distancing, personal hygiene and essential preventive measures (Table 2) (d) coping measures 26 activities related to the 8 domains of coping strategies viz distraction, distance socializing, physical exercise, adaptive cognitions, maladaptive cognitions, religious beliefs and practices, seeking information, activities related to family and home were included (Table 3).

The link to the questionnaire was shared with the help of email ids and social media platforms to the persons in contact with the investigators. These first point of contact participants were requested to share the survey link further to maximum people in contact with them. Eligibility criteria to participate in the study were age 18 years and above, resident of India, able to read and comprehend English and ready to provide informed consent to participate in the study. The data collection was initiated on 20th May 12 PM IST and closed on 
31st May 2020 at 12 PM IST. Descriptive analysis was used to assess the prevalence of the study variables among people.

\section{RESULTS}

1084 responses were recorded in survey, 16 were excluded as their forms were not complete. Consequently, responses of 1068 participant with mean age of $32.92 \pm 12.88$ years were included for analysis. The study comprised of $603(56.5 \%)$ males with mean age $35.12 \pm 13.40$ years and 465 (43.5\%) females with mean age of $30.06 \pm 11.59$ year the mean years of education of the all participants was $15.50 \pm 2.28$ years with $15.43 \pm 2.10$ years for males and $15.59 \pm 2.49$ years for females. Most of the study subjects were working with an overall proportion of $59.0 \%$. However the proportion of students was also remarkable with $33.5 \%$ males and $48.2 \%$ females. The participants were from 22 different states of India, however mostly from Uttar Pradesh, as mentioned below:

\begin{tabular}{|c|c|c|}
\hline & State & $\begin{array}{l}\text { Number of } \\
\text { Participants }\end{array}$ \\
\hline 1. & Andhra Pradesh & 05 \\
\hline 2. & Bihar & 10 \\
\hline 3. & Chhattisgarh & 05 \\
\hline 4. & Delhi & 59 \\
\hline 5. & Gujrat & 08 \\
\hline 6. & Haryana & 30 \\
\hline 7. & Himachal Pradesh & 07 \\
\hline 8. & Jammu and Kashmir & 07 \\
\hline 9. & Jharkhand & 06 \\
\hline 10. & Karnataka & 10 \\
\hline 11. & Kerala & 05 \\
\hline 12. & Maharashtra & 31 \\
\hline 13. & Meghalaya & 04 \\
\hline 14. & Madhya Pradesh & 16 \\
\hline 15. & Odisha & 04 \\
\hline 16. & Punjab & 16 \\
\hline 17. & Rajasthan & 11 \\
\hline 18. & Tamil Nadu & 05 \\
\hline 19. & Telangana & 05 \\
\hline 20. & Uttarakhand & 17 \\
\hline 21. & Uttar Pradesh & 789 \\
\hline 22. & West Bengal & 18 \\
\hline & Total participants & 1068 \\
\hline
\end{tabular}

\section{Perceived threat about COVID-19}

Table and figure 1.1 show that nearly half (51\%) of the participants reported feeling 'very high' anxiety and about $34 \%$ reported to have 'high' anxiety about the spread of corona virus. Some $18 \%$ expressed very high difficulty and (34\%) expressed very less difficulty in concentrating on professional work/study due to anxiety related to corona virus spread. $1 / 3 \mathrm{rd}(35 \%)$ reported very less whereas $15 \%$ very high frequency of thinking about corona. $67.4 \%$ reported that they had very less disturbed sleep and few (4.8\%) had very highly disturbed sleep due to thinking about COVID 19.

Table and figure 1.2 show that only few (9\%) participants reported that they have very high chances, on the other hand many (41.6\%) of them believed that they have 'very less' chances of getting infected with corona virus. Similarly few (8\%) reported that they have very high chances and $40.9 \%$ believed that it is very less likely that their family or friend could get infected with it. $34.1 \%$ believed that if they get infected with 
Corona virus there would be somewhat chances for them to be severely ill. In addition, $30.3 \%$ felt that if they hear someone having corona infection they fear somewhat that they may have it. $38.4 \%$ believe that if they catch CORONA there are 'very high' chances of major consequences on their life and few $(10.2 \%)$ thought it will have very less consequences on their life.

Table 1: Perceived threat among people amid COVID 19 pandemic:

\begin{tabular}{|c|c|c|c|c|c|}
\hline 1 & $\begin{array}{l}\text { Perceived threat } \\
\text { : Anxiety (related to COVID 19) }\end{array}$ & $\begin{array}{l}\text { Very less } \\
\text { Number } \\
{[\%]}\end{array}$ & Somewhat & High & $\begin{array}{l}\text { Very } \\
\text { high } \\
\text { Number } \\
{[\%]}\end{array}$ \\
\hline A & $\begin{array}{l}\text { To what extent are you anxious about } \\
\text { CORONA spread? }\end{array}$ & $\begin{array}{l}52 \\
(4.9 \%)\end{array}$ & $109(10.2 \%)$ & $\begin{array}{l}363 \\
(34.0 \%)\end{array}$ & $\begin{array}{l}545 \\
(51 \%)\end{array}$ \\
\hline B & $\begin{array}{l}\text { Because of the anxiety related to CORONA, } \\
\text { you are not able to concentrate on } \\
\text { work/study? }\end{array}$ & $\begin{array}{l}364 \\
(34.0 \%)\end{array}$ & $\begin{array}{l}262 \\
(24.5 \%)\end{array}$ & $\begin{array}{l}241 \\
(22.5 \%)\end{array}$ & $\begin{array}{l}202 \\
(18.9 \%)\end{array}$ \\
\hline C & $\begin{array}{l}\text { Do you keep thinking about CORONA } \\
\text { spread? }\end{array}$ & $\begin{array}{l}375 \\
(35.1 \%)\end{array}$ & $\begin{array}{l}298 \\
(27.9 \%)\end{array}$ & $\begin{array}{l}236 \\
(22.0 \%)\end{array}$ & $\begin{array}{l}160 \\
(15.0 \%)\end{array}$ \\
\hline $\mathrm{D}$ & $\begin{array}{l}\text { Is your sleep disturbed due to thinking about } \\
\text { CORONA? }\end{array}$ & $\begin{array}{l}721 \\
(67.4 \%)\end{array}$ & $\begin{array}{l}202 \\
(18.9 \%)\end{array}$ & $\begin{array}{l}93 \\
(8.7 \%)\end{array}$ & $\begin{array}{l}31 \\
(4.8 \%)\end{array}$ \\
\hline 1.2 & $\begin{array}{l}\text { Perceived Threat: } \\
\text { Threat of infection (related to COVID 19) }\end{array}$ & $\begin{array}{l}\text { Very less } \\
\text { Number } \\
{[\%]}\end{array}$ & Somewhat & High & $\begin{array}{l}\text { Very } \\
\text { high } \\
\text { Number } \\
{[\%]}\end{array}$ \\
\hline A & $\begin{array}{l}\text { How likely is it that you could get infected } \\
\text { with CORONA virus? }\end{array}$ & $\begin{array}{l}445 \\
(41.6 \%)\end{array}$ & $\begin{array}{l}360 \\
(33.7 \%)\end{array}$ & $\begin{array}{l}168 \\
(15.7 \%)\end{array}$ & $\begin{array}{l}96 \\
(9.0 \%)\end{array}$ \\
\hline B & $\begin{array}{l}\text { How likely is it that member of your family / } \\
\text { a friend could get infected with CORONA? }\end{array}$ & $\begin{array}{l}437 \\
(40.9)\end{array}$ & $\begin{array}{l}343 \\
(32.1 \%)\end{array}$ & $\begin{array}{l}203 \\
(19.0 \%)\end{array}$ & $\begin{array}{l}86 \\
(8 \%)\end{array}$ \\
\hline C & $\begin{array}{l}\text { Unfortunately, if you get infected with } \\
\text { CORONA, to what extent you will be } \\
\text { severely ill? }\end{array}$ & $\begin{array}{l}264 \\
(24.7 \%)\end{array}$ & $\begin{array}{l}365 \\
(34.1 \%)\end{array}$ & $\begin{array}{l}319 \\
(29.8 \%)\end{array}$ & $\begin{array}{l}121 \\
(11.3 \%)\end{array}$ \\
\hline $\mathrm{D}$ & $\begin{array}{l}\text { If you hear about someone having } \\
\text { CORONA, do you fear you may have it? }\end{array}$ & $\begin{array}{l}293 \\
(27.4 \%)\end{array}$ & $\begin{array}{l}324 \\
(30.3 \%)\end{array}$ & $\begin{array}{l}273 \\
(25.5 \%)\end{array}$ & $\begin{array}{l}179 \\
(16.7 \%)\end{array}$ \\
\hline $\mathrm{E}$ & $\begin{array}{l}\text { If you catch CORONA it will have major } \\
\text { consequences on your life? }\end{array}$ & $\begin{array}{l}109 \\
(10.2 \%)\end{array}$ & $\begin{array}{l}215 \\
(20.1 \%)\end{array}$ & $\begin{array}{l}335 \\
(31.3 \%)\end{array}$ & $\begin{array}{l}410 \\
(38.4 \%)\end{array}$ \\
\hline
\end{tabular}

\section{Lock down compliance and behaviour change}

Table 2 shows that not all but a large population (89.3\%) reported complying to the nationwide lockdown. A day before lock down began, majority $85.4 \%$ followed 'janta curfew', $59.3 \%$ reported staying at home all day and more $(66.7 \%)$ reported staying at home mostly. Majority $(89.6 \%)$ avoided large gathering of people, $87.3 \%$ avoided transportation and more than half $(67.2 \%)$ avoided going to shops.

As reported by participants majority maintained physical distance from others( $86.3 \%)$, avoiding shaking hands $(87.8 \%)$, avoided eating out $(86.4 \%)$, used sanitizers for hands $(85.9 \%)$, washed hands frequently with soap and water $(82.1 \%), 67.8 \%$ disinfected things at home and used masks $(82.1 \%)$. Nearly half of them (52.7\%) avoided even small gatherings. 
Figure 1.1: Perceived Threat (Anxiety related to the COVID outbreak)

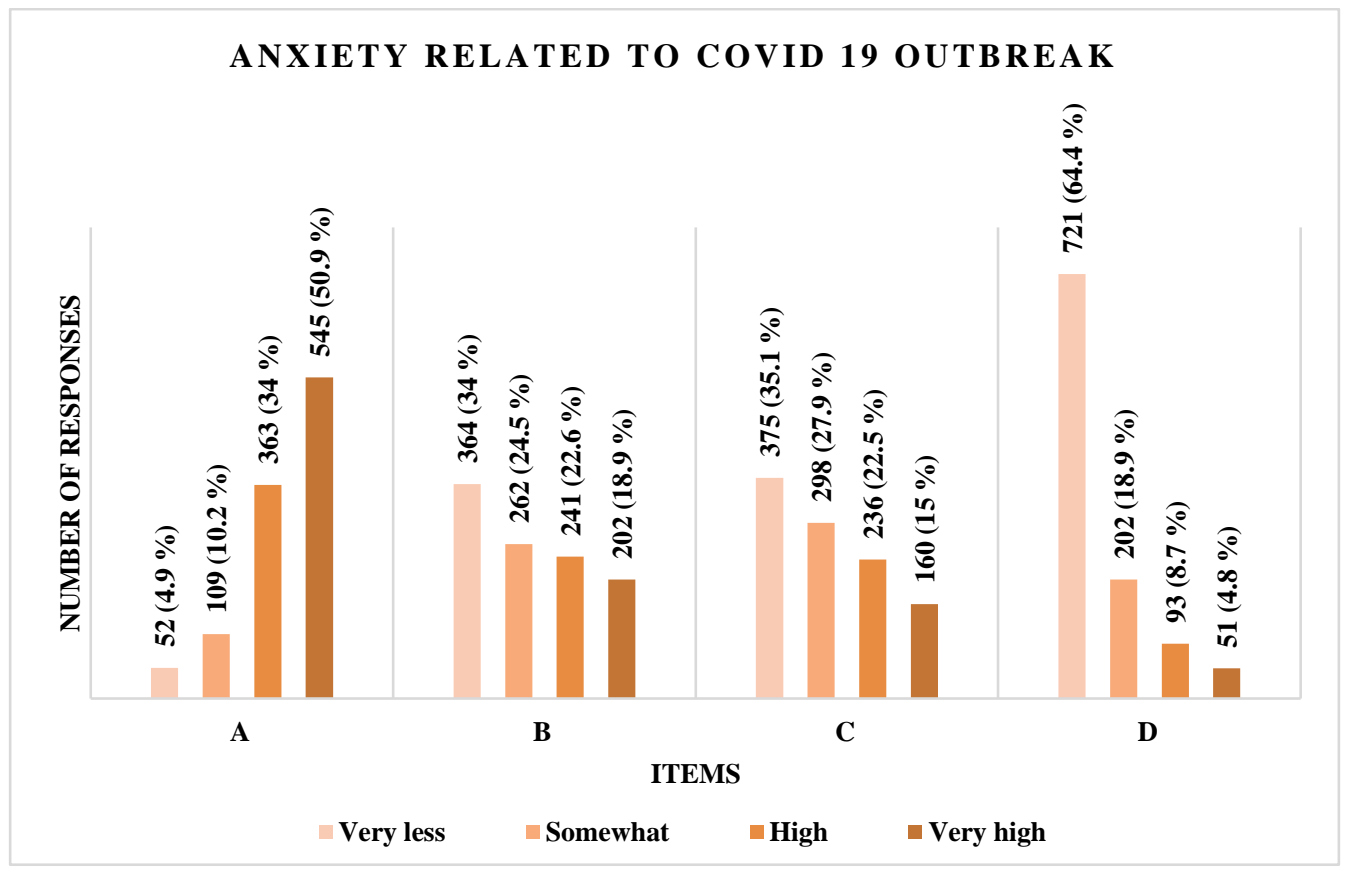

Figure 1.2: Perceived Threat (infection and its consequence)

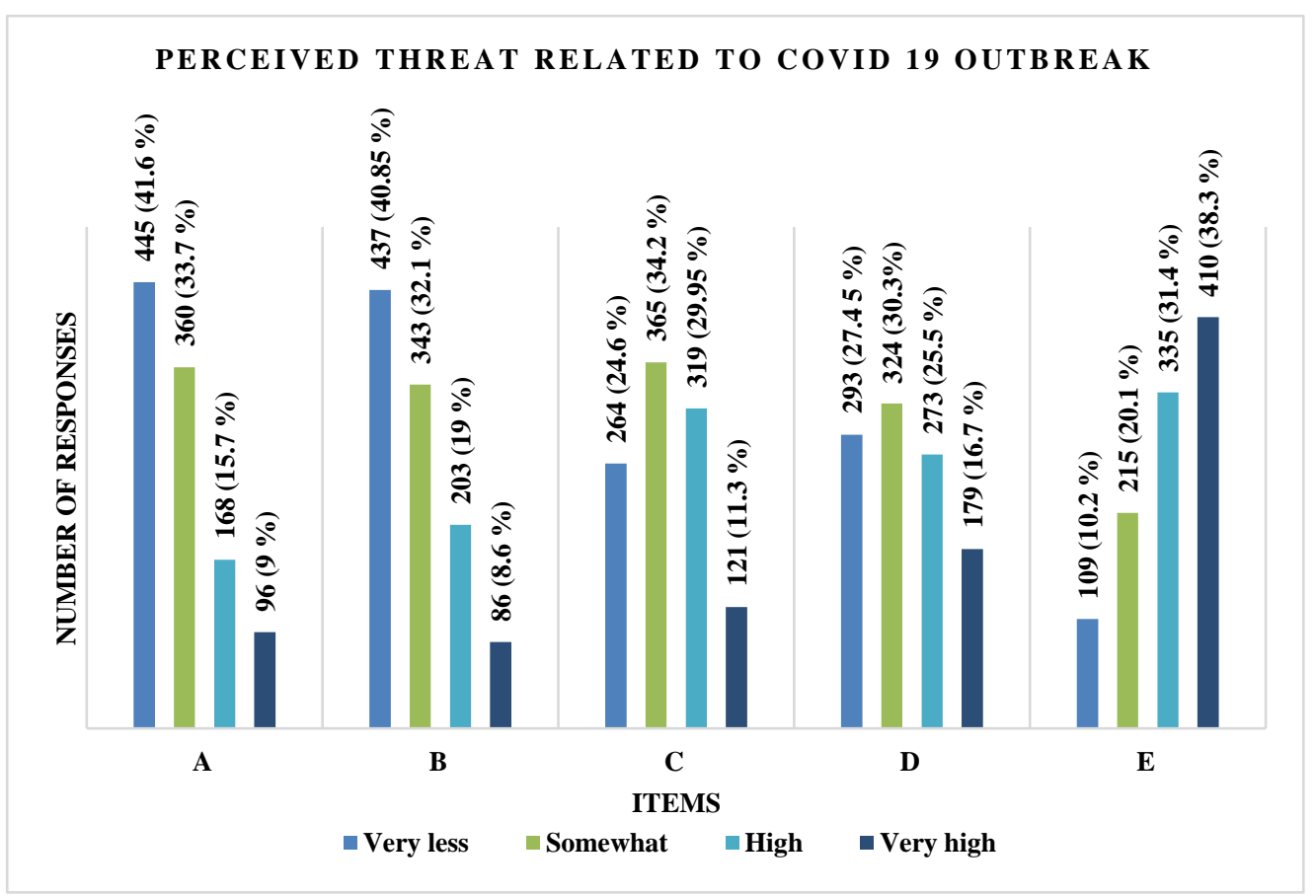

Table: 2. Lockdown compliance and behavior change amid COVID 19 pandemic:

\begin{tabular}{|l|l|l|}
\hline & Lockdown compliance : & Number [\%] \\
\hline 1. & Compliance to lockdown & $955(89.3 \%)$ \\
\hline 2. & Staying at home (all day) & $634(59.3 \%)$ \\
\hline 3. & Staying at home (mostly) & $712(66.7 \%)$ \\
\hline 4. & Followed 'janta curfew' on 22 march & $913(85.4 \%)$ \\
\hline
\end{tabular}




\begin{tabular}{|l|l|l|}
\hline 5. & Avoid transportation & $933(87.3 \%)$ \\
\hline 6. & Avoid large gatherings of people & $958(89.6 \%)$ \\
\hline 7. & Avoid going to shops & $718(67.2 \%)$ \\
\hline & Behavior change: & \\
\hline 1. & Avoid small gatherings ( 3-5 persons) & $563(52.7 \%)$ \\
\hline 2. & Avoid home deliveries & $684(64.0 \%)$ \\
\hline 3. & Avoid eating out & $924(86.4 \%)$ \\
\hline 4. & Avoid shaking hands & $939(87.8 \%)$ \\
\hline 5. & Maintaining physical distance from others & $923(86.3 \%)$ \\
\hline 6. & Avoiding out- door activity & $862(80.6 \%)$ \\
\hline 7. & Washing hands frequently with soap and water & $878(82.1 \%)$ \\
\hline 8. & Respiratory hygiene & $904(84.6 \%)$ \\
\hline 9. & Disinfect things at home & $725(67.8 \%)$ \\
\hline 10. & Use sanitisers for hands & $918(85.9 \%)$ \\
\hline 11. & Wearing mask & $882(82.5 \%)$ \\
\hline
\end{tabular}

\section{Coping strategies amid COVID 19 and lockdown}

As shown by table 3 , majority of respondents reported that the distraction techniques such as watching entertainment shows/movies (61.7\%), listening to music(58.1\%), reading books(52.7\%), using internet (58\%), communicating on phone (59.8\%) connecting on social media (51\%), adaptive cognitions such as telling one needs to have patience $65 \%$, telling oneself that the situation will improve (52\%), looking for something positive $(50.4 \%)$, having religious beliefs(59.2\%), taking care of family $(66 \%)$, doing house chores $(52 \%)$, indoor physical exercise $(64.6 \%)$ helped them to cope with the current pandemic. Some $(25 \%$ $50 \%$ ) reported yoga $(48.6 \%)$, meditation $(47.8 \%)$, cooking $(45.6 \%)$, watching news $(45.1 \%)$, helping the needy $(40.2 \%)$, thinking the situation is not too bad (30.1\%), praying to God $(39 \%)$ helps them to cope. A Few $(<25 \%)$ reported surfing about corona (20.7\%) and maladaptive cognitions like blaming other countries $(11.8 \%)$, blame oneself or lifestyle $(12.6 \%)$, denial that there is crisis $(21.3 \%)$. The least reported coping technique was the maladaptive thinking of feeling one is doomed (5.4\%).

Table 3: Coping strategies among people amid COVID 19 pandemic:

\begin{tabular}{|l|l|l|}
\hline S.N. & Coping strategies: & Number of participants (\%) \\
\hline $\mathbf{1}$ & Distraction techniques & $620(58.1 \%)$ \\
\hline A & Listening to Music & $659(61.7 \%)$ \\
\hline B & Watching entertainment shows/movies & $563(52.7 \%)$ \\
\hline C & Reading books & $619(58.0 \%)$ \\
\hline D & Using internet & \\
\hline 2 & Information seeking & $482(45.1 \%)$ \\
\hline A & Watching news & $221(20.7 \%)$ \\
\hline B & Surfing about CORONA & $289(27.1 \%)$ \\
\hline C & Keeping away from news & \multicolumn{2}{|l|}{} \\
\hline $\mathbf{3}$ & Distance Socializing & $639(59.8 \%)$ \\
\hline A & Communicating with others on phone & $545(51.0 \%)$ \\
\hline B & Connecting on social media & $429(40.2 \%)$ \\
\hline C & Helping the needy & \multicolumn{2}{|l|}{} \\
\hline $\mathbf{4}$ & Maladaptive cognitions & $126(11.8 \%)$ \\
\hline A & Blame other country/countries & $135(12.6 \%)$ \\
\hline B & Blame oneself/ life style & $58(5.4 \%)$ \\
\hline C & Feel 'I am doomed' & \multicolumn{2}{|l}{} \\
\hline & &
\end{tabular}




\begin{tabular}{|l|l|l|}
\hline D & Tell myself that there is no crisis & \multicolumn{2}{l|}{$228(21.3 \%)$} \\
\hline $\mathbf{5}$ & Adaptive cognitions: & $538(50.4 \%)$ \\
\hline A & Looking for something positive & $694(65 \%)$ \\
\hline B & Telling I need to have patience & $555(52 \%)$ \\
\hline C & Telling myself that situation will improve & $322(30.1 \%)$ \\
\hline D & Thinking the situation is not too bad & \multicolumn{2}{|l|}{} \\
\hline $\mathbf{6}$ & Religious beliefs and practices : & $632(59.2 \%)$ \\
\hline A & Having faith in God/ having religious beliefs & $417(39.0 \%)$ \\
\hline B & Praying to God & \multicolumn{1}{|l|}{} \\
\hline $\mathbf{7}$ & Activities related to family \& home: & Taking care of family \\
\hline A & Taking care of family & Doing house chores \\
\hline B & Doing house chores & $487(45.6 \%)$ \\
\hline C & Cooking & \multicolumn{2}{|l}{} \\
\hline $\mathbf{8}$ & Physical exercise and meditation: & $690(64.6 \%)$ \\
\hline A & Indoor physical exercise & $511(47.8 \%)$ \\
\hline B & Meditation & $519(48.6 \%)$ \\
\hline C & Yoga &
\end{tabular}

\section{DISCUSSION}

The present study explored perceived threat, behavior change, lockdown compliance and coping strategies associated with COVID 19 outbreak in India. There were 1068 Indian participants including $56.5 \%$ males and $43.5 \%$ females with mean age of $32.92 \pm 12.88$ years and mean $15.50 \pm 2.28$ years of education. Most of the study subjects were working with an overall proportion of $59.0 \%$. The majority of participants came from U.P. $(n=789)$, Delhi $(n=59)$, Maharashtra $(n=31)$ and Haryana $(n=30)$.

The perceived threat variable of the study had two aspects -first anxiety and preoccupation and second infection and its consequences. The results of our study show that majority of the participants reported experiencing 'very high' or 'high' anxiety (51\% and 34\% respectively) about the spread of corona virus. This can be understood as such situations are unpredictable and constant fear of the unknown might result in anxiety. Also majority of the participants belonged to Maharashtra, Delhi, Haryana and U.P. where maximum number of COVID 19 cases are reported. Many studies done in the past on viral epidemic revealed similar results where upto 50\% subjects reported anxiety and worry [16-19]. Although the sample reported high anxiety but this anxiety did not cause much disturbance in concentration on work/study (18.9\%-very high, $22.5 \%$ - high), preoccupation with illness (15\%-very high, $22 \%$ - high) or sleep ( $4.8 \%$ - very high, $8.7 \%$ - high). It is possible that as majority of the population consisted of working professionals or students and were able to use distractions to cope up with the situation thus no significant disturbance in functioning was found.

The second aspect of perceived threat was fear of infection and its consequences. Our results show that many participants $(41.6 \%, 33.7 \%)$ stated very less or somewhat threat of getting infected with COVID 19 infection. Similarly many $(40.9 \%, 32.1 \%)$ felt very less or somewhat likelihood that member of the family or a friend could get infected. This can be understood with the help of biases that people in order to avoid negative emotions start exhibiting like The 'optimism bias' people exhibit which further makes them underestimate the likelihood of contracting a disease [20] and avoiding the public health warnings [21]. This underestimation may further lead to increased risk of contracting the virus and avoiding public health warnings. The current continuous surge in the number of cases in India could possibly be understood with the help of this optimism bias [14].

An interesting finding was that although few participants $(34.1 \%, 29.8 \%)$ reported somewhat or high threat of getting severely ill if they get infected with CORONA, more participants $(38.4 \%, 31.3 \%)$ reported very high or high threat of COVID 19 to have major consequences on life. This is possible as $59 \%$ of the participants are working professionals thus the thought of catching the virus might result in inability to 
continue their jobs as well as spending time with their family. As there is no cure for the virus thus many might be worried about their ability to recover from it as well. This may also be due to the concern about the health consequences one might face and its impact on the life of an individual.

Second variable of the study was lockdown compliance and behaviour change. Lockdown compliance included strict measures from the government. A large population (89.3\%) reported complying with the nationwide lockdown. 85.4\% followed 'janta curfew'. Majority (89.6\%) avoided large gathering of people, $87.3 \%$ avoided transportation participants majority maintained physical distance from others $(86.3 \%)$, avoiding shaking hands $(87.8 \%)$, avoided eating out $(86.4 \%)$, used sanitizers for hands $(85.9 \%)$, washed hands frequently with soap and water (82.1\%). This behavior change and compliance can be attributed because of the health anxiety among the people which further makes them to judiciously take preventive measures. The role of World health organization in promoting programs for hand hygiene and other has provided the basic education for such compliance [9]. This indicates the success of government measures taken which were based on modification in habits and lifestyle pattern of people.

Another variable of the study was coping mechanisms used by people during crisis. As COVID 19 is a new world for everyone and everything seems to be indefinitely on hold, there are a lot of uncertainties surrounding the current situation which results in a lot of stress and anxiety which needs to be dealt with. There were eight coping mechanisms explored in the study. The use of distractions like watching movies (61.7\%), listening to music (58.1\%) and using the internet (58\%) helped people in dealing with anxiety and stress. People also used distance socializing like communicating on phone $(59.8 \%)$, communicating on social media (51\%) to manage their stress. During the times of social distancing this coping mechanism helped in social connectedness. Being able to connect with our loved ones helps in finding support and sharing of one's feelings. Other adaptive coping mechanisms used were engaging in exercise like indoor exercise (64.6\%), meditation (47.8\%) and yoga (48.6\%). People also used religious activities like keeping faith in God (59.2\%) to help deal with the situation. Many adaptive coping mechanisms were used like telling oneself to have patience $(65 \%)$, believing that situation will improve $(52 \%)$ and looking for something positive (50.4\%). Very few people engaged in maladaptive coping mechanisms like blaming others $(11.8 \%)$, blaming self $(12.6 \%)$. The use of these adaptive coping mechanisms which involved in confronting the problem, recognizing the unhealthy emotional reaction helped people prevent adverse effect on their concentration, work and sleep.

\section{CONCLUSION}

Thus, largely the study points out that COVID 19 pandemic is being perceived as a threat by the people which is causing increase in anxiety among people. This anxiety is motivating people to follow government directions for prevention of the spread of the virus. The major coping mechanism being used by the people is distractions, socializing as well as using adaptive coping strategies. Due to the use of adaptive coping mechanism the people were found to be able to deal with the situation without any significant preoccupation, disturbance in sleep and concentration during work or study. But at the same time, in the current scenario there is a concern for India, as due to surge in COVID 19 positive persons and an indication towards 'optimism bias' prevalent in people there are chances of poor compliance to government guidelines on behavior change related to social distancing and sanitization among people. The strengths of the study include large sample size from across the country. The findings of the study will be helpful in designing programs and government measures for the people in future focusing on ensuring compliance to the guidelines and using adaptive coping strategies. The limitations of the study include use of non-standardized tool for assessing the variables, the form used for data collection was in English and was online thus non English speaking population as well as people who do not use online platforms could not be included. For further studies the individual variables can be assessed separately in more detail with the use of structured tools.

\section{REFERENCES}

1. World Health Organization, (2020a). Coronavirus disease 2019 (COVID-19): situation report, 72 
2. Li SW, Wang Y, Yang YY, Lei XM, Yang YF. Analysis of influencing factors of anxiety and emotional disorders in children and adolescents during home isolation during the epidemic of novel coronavirus pneumonia. Chinese J Child Health 2020;28(3):1-9.

3. Ho CS, Chee CY, Ho RC. Mental health strategies to combat the psychological impact of COVID-19 beyond paranoia and panic. Ann Acad Med Singapore 2020;49(1):1-3.

4. Goyal K, Chauhan P, Chhikara K, Gupta P, Singh MP. Fear of COVID 2019: First suicidal case in India. Asian J Psychiatry 2020;49:101989.

5. Bao Y, Sun Y, Meng S, Shi J, Lu L. 2019-nCoV epidemic: address mental health care to empower society. Lancet 2020;395(10224):37-8.

6. Hsiehchen D, Espinoza M, Slovic P. Political partisanship and mobility restriction during the COVID-19 pandemic. Public Health 2020;187:111-4.

7. Van der Linden S. The social-psychological determinants of climate change risk perceptions: Towards a comprehensive model. J Environ Psychol 2015;41:112-24.

8. Van der Linden S. Determinants and measurement of climate change risk perception, worry, and concern. The Oxford Encyclopedia of Climate Change Communication. Oxford University Press, Oxford: UK; 2017.

9. World Health Organization (2020b) https://www.who.int/publications/i/item/covid-19-strategyupdate---14-april-2020

10. The Hindu (2020a) https://www.thehindu.com/news/national/social-distancing-measures-cantcontinue-forever-says-union-health-minister-harsh-vardhan/article31531956.ece

11. ICMR (2020) https://www.icmr.gov.in

12. Floyd DL, Prentice Dunn S, Rogers RW. A meta-analysis of research on protection motivation theory. J Appl Soc Psychol 2000;30(2):407-29.

13. The Hindu (2020b). https://www.thehindu.com/news/national/india-coronavirus-lockdown-july-62020-live-updates/article31999016.ece

14. Main A, Zhou Q, Ma Y, Luecken LJ, Liu X .Relations of SARS-related stressors and coping to Chinese college students' psychological adjustment during the 2003 Beijing SARS epidemic. J Counsel Psychol 2011;58(3):410-9.

15. Jungmann SM, Witthöft M. Health anxiety, cyberchondria, and coping in the current COVID-19 pandemic: Which factors are related to coronavirus anxiety? J Anxiety Disord 2020;73:102239.

16. Bults M, Beaujean DJ, de Zwart O, Kok G, van Empelen P, van Steenbergen JE, Richardus JH, Voeten HA. Perceived risk, anxiety, and behavioural responses of the general public during the early phase of the Influenza A (H1N1) pandemic in the Netherlands: results of three consecutive online surveys. BMC Pub Health 2011;11:2.

17. Goulia P, Mantas C, Dimitroula D, Mantis D, Hyphantis T. General hospital staff worries, perceived sufficiency of information and associated psychological distress during the A/H1N1 influenza pandemic. BMC Infect Diseases 2010;10:322.

18. Jalloh MF, Li W, Bunnell RE, Ethier KA, O’Leary A, Hageman KM, Sengeh P, Jalloh MB, Morgan O, Hersey S, Marston BJ. Impact of Ebola experiences and risk perceptions on mental health in Sierra Leone, July 2015. BMJ Glob Health 2018;3:e000471.

19. Lau JT, Griffiths S, Choi KC, Tsui HY. Avoidance behaviors and negative psychological responses in the general population in the initial stage of the H1N1 pandemic in Hong Kong. BMC Infect Diseases 2010;10:139.

20. Sharot T. The optimism bias. Current Biol 2011;21:941-5.

21. Tandon R. The COVID-19 pandemic, personal reflections on editorial responsibility. Asian J Psychiatr.2020;50:102100

$* * * * * * * * * * * * * * * * * * * * * * * * * * * * * * * * * * * *$

Acknowledgements - Nil.

Conflict of Interest - Nil

Funding - Nil 